\title{
Od żartu do anegdoty. Komiczne aspekty pamiętników wojennych XVII wieku
}

Tomasz Ślęczka 


\section{Tomasz Ślęczka}

\section{Od żartu do anegdoty. Komiczne aspekty pamiętników wojennych XVII wieku}

\section{Ustalenia wstępne}

Drzedmiotem moich rozważań będzie wstępna analiza elementów komicznych, ujawniających się na kartach siedemnastowiecznych polskich pamiętników wojennych ${ }^{1}$. Przez komizm rozumieć będę

właściwość charakterystyczną dla pewnych konfiguracji zjawisk spotykanych w życiu lub przedstawianych przez sztukę, wywołującą u obserwatora, mogącego być równocześnie uczestnikiem lub sprawcą takich konfiguracji, reakcję w postaci śmiechu i wesołości wykluczającą zarazem silne emocje negatywne ${ }^{2}$.

Nie jest to, rzecz jasna, jedyna definicja tego zjawiska, funkcjonująca w obiegu naukowym, jednak biorąc pod uwagę rozmaitość koncepcji, wyjaśniających (czy raczej: usiłujących wyjaśnić) istotę komizmu, poprzestać wypada na jednej, której bezsporną zaletą jest zwięzłość oraz prostota. Nie miejsce też tutaj na omawianie poszczególnych teorii; zresztą rzetelny przegląd stanu badań w tej dziedzinie znaleźć można w niedawno wznowionej i zaktualizowanej pracy Danuty Buttler ${ }^{3}$ oraz książce Beaty Grochali.

${ }^{1}$ Określenie „pamiętniki wojenne” ma tu czysto porządkujący charakter, z jego zakresu nie wyłączam diariuszy ani innych form literatury pamiętnikarskiej.

2 Stounik terminów literackich, red. J. Sławiński, Wrocław 1988, s. 230.

${ }^{3}$ Zob. D. Buttler, Polski dowcip jezykowy, Warszawa 2001, s. 7 i nast. oraz XII-XIII.

${ }^{4}$ Zob. B. Grochala, Komizm jezykouy w felietonach Antoniego Stonimskiego, Łódź 2006, s. 12 i nast. 
W ironii widzieć $\mathrm{z}$ kolei będziemy zadomowiony w tradycji retorycznej trop ${ }^{5}$, jak pisał Mirosław Korolko, „uwydatniający przeciwieństwo semantyczne rzeczy wyrażanej słowami"6. Wprawdzie ironia jako kategoria stylu oraz — szerzej - kategoria estetyczna doczekała się współcześnie wcale obfitej bibliografii, to jednak z uwagi na niesporność tego tropu na tle tradycji bardziej szczególowe rozważanie istoty ironii nie wydaje się ani konieczne, ani pożądane. Doniosłe znaczenie ma również fakt, iż posługujący się tym tropem autorzy sięgali po niego jako po środek pochodzący $z$ arsenału chwytów retorycznych, powszechnie znany i ceniony. Można od razu zasygnalizować, że ironia $\mathrm{w}$ dziełach naszych pamiętnikarzy będzie poza nielicznymi przypadkami pełniła funkcje satyryczną, czasami przechodząc w gorzki sarkazm.

Wybór siedemnastego stulecia nie jest przypadkowy. Pozwala ogarnąć całkiem znaczącą ilość tekstów (choć z pewnymi ograniczeniami), traktujących o tych samych wydarzeniach. Ze względu na liczbę konfliktów, w jakich obywatele Rzeczypospolitej mogli brać udział, wiek XVII dostarczał znacznie więcej sposobności do wykazania się militarnymi przewagami niż na przykład znacznie pod tym względem „spokojniejsze” (przynajmniej w polskiej sytuacji) osiemnaste stulecie.

\section{Przegląd źródeł}

Spośród stosunkowo znacznej liczby pamiętników, które można uznać za wojenne, wybrałem te, które doczekały się nowoczesnych krytycznych lub przynajmniej popularnonaukowych edycji. Zdecydowałem się też mniej uwagi poświęcić najbardziej chyba znanym - a co za tym idzie, najbardziej naukowo wyeksploatowanym - tekstom Jana Chryzostoma Paska ${ }^{7}$ oraz Samuela i Bogusława Maskiewiczów ${ }^{8}$, odsyłając raczej do dokonanych już ustaleń. Natomiast pozostałe utwory nie stały się powodem powstania chocby zbliżonej wielkością bibliografii, dlatego też w nich przede wszystkim szukałem podstawy materiałowej mych badań. Rzecz jasna, wskutek przyjętych założeń nie rości sobie ona pretensji do kompletności (przekraczałaby zresztą wtedy znacząco ramy artykułu), niemniej jednak nie wydaje się, by szerzej zakrojona kwerenda była w stanie znacząco odmienić me ustalenia; różnice mogłyby dotyczyć raczej skali zjawiska, nie zaś jego samej zasady.

Podstawę materiałową mych badań stanowią dzieła następujących autorów: Stanisława Niemojewskiego ${ }^{9}$, Stanisława Żółkiewskiego ${ }^{10}$, Samuela i Bogusława Maskie-

\footnotetext{
${ }^{5} \mathrm{Z}$ naszego punktu widzenia nie ma specjalnego znaczenia rozstrzyganie problemu, czy ironia jest tropem czy figurą; nie przesądzając o tym, będziemy traktować ją jak trop.

${ }^{6}$ M. Korolko, Sztuka retoryki. Przewodnik encyklopedyczny, Warszawa 1990, s. 105.

7 Zob. m. in. J. Rytel, „Pamiętniki” Paska na tle pamiętnikarstwa staropolskiego, Wroclaw 1962.

8 Zob. M. Bauer, Obraz państwa moskiewskiego i jego mieszkańców w pamiętniku Samuela Maskieuricza, „Napis” seria 12: Krwauy świt, mroczny dzień..., 2006, s. 171-182. Tam dalsza bibliografia.

${ }^{9}$ Zob. S. Niemojewski, Diariusz drogi spisanej i różnych przypadków pociesznych i żałosnych prowadzqc córkę Jerzego Mniszka, Maryne, Dymitrowi Iu'anowiczowi w roku 1606, opr. R. Krzywy, Warszawa 2006.

${ }^{10}$ Zob. S. Żółkiewski, Poczq̨tek i progres wojny moskiewskiej, opr. W. Sobieski, Kraków 1920.
} 
wiczów ${ }^{11}$, Józefa Budziły ${ }^{12}$, Filipa, Michała i Teodora Obuchowiczów ${ }^{13}$, Jana Chryzostoma Paska ${ }^{14}$, Mikołaja Jemiołowskiego ${ }^{15}$, Jana Poczobuta Odlanickiego ${ }^{16}$, Stanisława Druszkiewicza $^{17}$, Jana Cedrowskiego i Jana Floriana Drobysza Tuszyńskiego ${ }^{18}$, Marcina Kątskiego ${ }^{19}$, Mikołaja Dyakowskiego ${ }^{20}$ i Aleksandra Skorobohatego ${ }^{21}$. Nie wszystkie one w równym stopniu nadają się do wyzyskania, niemniej jednak na ich podstawie można pokusić się o wyciągnięcie pewnych, wstępnej oczywiście natury, wniosków.

Nadmienić wreszcie wypada, że - co w końcu wydaje się oczywiste - nie wszyscy autorzy cechują się zbliżonym choćby poczuciem humoru; dla niektórych wojna okazuje się na tyle poważnym zajęciem, że nawet lekkie zabarwienie narracji akcentami humorystycznymi okazuje się czystą niemożliwością (jak było w przypadku Jana Cedrowskiego, Marcina Kątskiego i Aleksandra Skorobohatego), pozostałych autorów różni zaś natężenie tych akcentów.

\section{3. Żarty i dowcipy}

\subsection{Ironiczne określenia „męstwa” swoich}

Najczęściej spotykaną postacią ironii jest jej klasyczne zastosowanie, wyrażające się w wykorzystywaniu pozytywnych, pochwalnych określeń w zestawieniu z zachowaniami o diametralnie odmiennym charakterze. Na ogół będziemy natykali się na określanie postaci tchórzliwych lub tylko nieudolnych bohaterskimi epitetami.

Jemiołowski wspomina pospolitaków, którzy po beresteckiej wiktorii od razu wymówili królowi służbę, dowodząc, iż wedle prawa powinni są mu jedynie dwa dalsze tygodnie służby. Pamiętnikarz potępia taką postawę, samo prawo krytykuje, zaś korzystających z niego żołnierzy ironicznie nazywa „miłośnikami Rzeczypospolitej”22.

11 Zob. Pamiętniki Samuela i Bogusława Kazimierza Maskiewiczów, opr. A. Sajkowski, Wrocław 1961.

12 Zob. J. Budziło, Wojna moskiewska wzniecona i prowadzona z okazji fałszynuch Dymitrów od 1603 do 1612 r., opr. J. Byliński, J. Długosz, Wrocław 1995.

13 Zob. Pamiętniki Filipa, Michała i Teodora Obuchowiczów (1630-1707), red. A. Rachuba, opr. H. Lulewicz, A. Rachuba, Warszawa 2003.

14 Zob. J. Pasek, Pamiętniki, opr. W. Czapliński, Kraków 1979.

${ }^{15}$ Zob. M. Jemiołowski, Pamiętnik dzieje Polski zawierający, opr. J. Dzięgielewski, Warszawa 2000.

${ }^{16}$ Zob. J. W. Poczobut Odlanicki, Pamiętnik, opr. A. Rachuba, Warszawa 1987.

17 Zob. S. Z. Druszkiewicz, Pamiętniki 1648-1697, opr. M. Wagner, Siedlce 2001.

${ }^{18}$ Zob. Dwa pamiętniki z XVII wieku, opr. A. Przyboś, Wrocław-Rzeszów 2006.

${ }^{19}$ Zob. M. Kątski, Diariusz uypraù wiedeńskiej króla Jana III w roku 1683 przez Marcina Kątskiego kasztelana lwowskiego, generała artylerii koronnej spisany, opr. B. Królikowski, Lublin 2003.

20 Zob. Dyaryusz wideńskiej okazyji Jmci Pana Mikołaja na Dyakowcach Dyakowskiego podstolego latyczewskiego, opr. J. Kosiński, J. Długosz, Warszawa 1983.

21 Zob. A. Skorobohaty, Diariusz, opr. T. Wasilewski, Warszawa 2000.

${ }^{22}$ M. Jemiołowski, Pamiętnik..., op. cit., s. 85. 
Identyczny zabieg stosuje i później, kiedy to negatywnie ocenia Tatarów, formalnie sojuszników podczas wojny ze Szwedami w 1655, którzy odmówili udziału w walce „świętem się jakimsi swoim wymawiając, że posiłku żadnego w święto dawać się nie godzilo, osobliwi ś wi ę to s z kow i e [podkr. T. Ś.]"23. Efekt krytyczny osiąga poprzez typową dla ironii pozorną pochwałę oczywiście negatywnie ocenianego postępowania $^{24}$. Do tak stosowanej ironii przyjdzie mu jeszcze sięgać niejednokrotnie ${ }^{25}$. Ponadto zauważyć należy wykorzystanie deminutivum w roli nośnika ironii; jak dowiódł Michał Sarnowski, w języku polskim zdrobnienia mają znaczny potencjał ironiczny i mogą być $\mathrm{w}$ tej roli stosowane na szeroką skalę̧.

Nie zawsze zresztą żarty Jemiołowskiego okazują się najwyższej próby. Opisując wysadzenie zamku w Sandomierzu przez Szwedów, kiedy to zginęło wielu Polaków i Litwinów, plądrujących opuszczone przez wroga zabudowania, nie znajduje żadnych słów współczucia dla ofiar szwedzkiego podstępu (Szwedzi podłożyli bowiem - jak byśmy to dziś nazwali — miny z opóźnionym zapłonem), a nawet przeciwnie - ich śmierć kwituje szyderczym żartem. Pisze bowiem:

Godni zaprawdę takowej kary ci co tam byli [...] Aleć doznał niejeden prawdy, kiedy jako ptastwo, jedni bez rąk, drudzy bez nóg, bez głowy po powietrzu latać musieli, aż się wpól Wisły opierali [...] Na kilkaset jednak tych ochotnisiów [co zginęli] rachowano ${ }^{27}$.

Tego rodzaju porównanie nie kłócilo się oczywiście z barokowym poczuciem estetyki, negatywna ocena nieposłusznych wyraźnemu, hetmańskiemu rozkazowi żołnierzy jest również zrozumiała, mimo to jednak trudno tego rodzaju żart uznać za płód zacnego dowcipu — nawet ironicznie brzmiące w tym miejscu deminutivum „ochotnisiowie" nie łagodzi ponurej wymowy autorskiego komentarza do opisanego epizodu.

Podobnymi środkami (choć na ogół wyższej próby) chętnie posługiwał się również Poczobut Odlanicki. Gdy wspomina o pewnym wydarzeniu z 1660 roku, kiedy to oblegający Bowsk Polacy okazali się tak nieudolnymi strażnikami, że dwu Szwedów z Rygi przejechało w samo południe przez obóz i przez nikogo nie niepokojonych dostało

\footnotetext{
${ }^{23}$ Ibidem, s. 128.

${ }^{24}$ Możliwa wydaje się również interpretacja, że Jemiołowski nie znał się na tatarskich wierzeniach, zaś zachowanie sojuszników dałoby się wytłumaczyć, to jednak uprzednio poczyniona wzmianka, iź święto nie uniemożliwiało Tatarom plądrowania okolicy, upewnia czytelnika w słuszności ironii obecnej w tym fragmencie dzieła.

${ }^{25} \mathrm{~Np}$. łupiących zwłoki na pobojowisku chłopów określi mianem „cnotliwych” (s. 84), porywających jasyr Tatarów nazwie „niepospolitymi” opiekunami (s. 130), uciekających przed Szwedami wieśniaków nazwie „rycerstwem chłopskim”, które rozpierzchło się w mgnieniu oka (s. 184).

${ }_{26}$ Zob. M. Sarnowski, Deminutiwum jako znak ironii, w: Jezyk a kultura, t. 3, red. J. Puzynina, J. Anusiewicz, Wrocław 1991, s 41-50.

${ }_{27}^{27}$ M. Jemiołowski, Pamiętnik..., op. cit., s. 187.
} 
się do oblężonego miasta, pamiętnikarz czyni przytyk naszym żołnierzom, stwierdzając, iż "tacy obrali się bezpiecznisiowie" ${ }^{28}$. Ponownie dostrzec możemy wykorzystanie i zdrobnienia, i kontrastu dla wyrazistego podkreślenia braku starania o zabezpieczenie swojego obozu, a tym samym wojskowej niekompetencji.

Nie własnych żołnierzy wprawdzie, lecz sąsiadów - towarzyszy broniących posiadłości pamiętnikarza przed zajazdem — dotyczy kolejny z przykładów wykorzystania ironii w funkcji rzekomej pochwały. Odlanicki wspomina, jak to — mając świadomość zbliżającego się nieuchronnie zajazdu — zaraz po pogrzebie spadkodawcy ruszył samotnie do zagrożonej wsi i swym przyjazdem śmiertelnie wystraszył zgromadzonych tam dziesięciu pomocników ${ }^{29}$. Pisze o tym:

Jakoż zatem pana Krzysztofa Łapę, jak do uciekania gotowego, bo mię samego obaczywszy ledwie w koni dziesiątek, chcieli byli uciekać, tak dobrzy kawalerowie byli ${ }^{30}$.

Ten brak odwagi nie zniechęcil naszego pamiętnikarza do miecznika trockiego, bo w dalszych partiach dzieła natykamy się na wzmiankę, iż Krzysztof Łapa trzymał do chrztu jedną z córek Poczobuta, Zofię. Cała historia z okazanym brakiem odwagi okazała się więc niewiele znaczącym epizodem, zaś ironiczna ocena - jedynie szybko przemijającym rozbawieniem.

\subsection{Ironia wobec wroga}

Przywoływany już Poczobut, relacjonując walki z Moskalami w roku 1664, wspomina o braku zgody między dowódcami w kwestii przemarszu przez las. Król domagał się stoczenia bitwy na gęsto zalesionym terenie za rzeką Deśnią, jednak obecni tam hetmani i wyżsi dostojnicy odwiedli monarchę od tak niebezpiecznego pomysłu. Pamiętnikarz komentuje:

Zaledwo Króla JM. od tego odwiedli, za co chwała Najwyższemu, bo by pewnie wojsko pogubił w tym gęstym lesie, w którym chciał szykować

\footnotetext{
${ }^{28}$ J. W. Poczobut Odlanicki, Pamiętnik, op. cit., s. 136.

29 Poczobut nie jest konsekwentny w swej relacji: wpierw mówi o 10 koniach — zatem należy domniemywać, że łącznie było ich 11, w dalszej części zaś o tym, że zajezdnicy przestraszyli się ośmiu obrońców (a jednocześnie nie wspomina ani o ewentualnych poległych, ani o dezerterach). Nie jest to zresztą kwestia istotna, ważne, że obrońców było niewielu, co z kolei określać będzie niefortunnych napastników, którzy przerazili się tak nielicznej drużyny; niemniej ironia w ich obrazie nie została wyrażona wprost, nie doczekali się też odpowiednio pozytywnego i pochwalnego określenia, jednak z kontekstu ewidentnie wynika, jak Poczobut widział ich „odwage” - nawet jeżeli na tchórzostwie przeciwników przyszło mu skorzystać.
}

${ }^{30}$ Ibidem, s. 279. 
usaryją, w której nadzieja wszytka była, gdyż przecież czternaście chorągwi było usarskich, a tam by żadnego efektu nie sprawiła w tym lesie, ale by marnie zginęła od tych leśnych ptaszków ${ }^{31}$.

W tym przypadku — jak sądzę - deminutywne określenie przeciwnika mianem „leśnych ptaszków”, aczkolwiek zdecydowanie przenośne i lekko ironicznie zabarwione - nie pełni jednak funkcji deprecjonującej moskiewskich żołnierzy, którym zresztą nasz pamiętnikarz nigdy nie odmawiał ani męstwa, ani wojennej dzielności.

Podobnie lekko tylko ironiczny wydźwięk ma element charakterystyki postępowania Karola Gustawa, który po wydostaniu się z wideł Wisły i Sanu

nie tak dalece oprócz prowiantów miesczan i wieśniaków nie krzywdząc, dwory tylko slacheckie, a kościoły rabować lubo nie kazał, ale też bardzo nie zabranial ${ }^{32}$.

Lekko humorystycznie zabarwiona jest tu ocena działania szwedzkiego monarchy, który „bardzo” nie zakazał własnym żołnierzom plądrowania dóbr szlacheckich oraz kościelnych.

Ironiczny charakter ma również opis szybkiego odwrotu szwedzkiego generała Douglasa. Poczobut tak kreśli całą scenę:

Gdzie nazajutrz, mając w pamięci furyją wczorajszą Duklasową, z którą był przyszedl, chcąc w polu zwieść bitwę marsową jako lew srogi zajuszony, ażci się ochłonąwszy w gniewie, obrócił się w tchórza. Co daj Boże każdemu naszemu i ojczyzny naszej nieprzyjacielowi, aby każdy z taką zawziętością uciekaß ${ }^{33}$.

Efekt komiczny zostaje tu osiągnięty z jednej strony przez kontrastowe zestawienie konwencjonalnych, wskazujących na wojenną dzielność określeń („bitwa marsowa”, „lew srogi”) z panicznym odwrotem, z drugiej zaś strony efekt ten wzmacniany jest wspomnianym, pobożnym życzeniem, by tak postępował każdy nieprzyjaciel. Nie sądzę wprawdzie, by Poczobutem przy wyrażaniu tego życzenia kierowało poczucie komizmu (bo zostało ono wypowiedziane zupełnie serio), jednak w kontekście całej sceny nabiera ono nowego, nieoczekiwanego i niezamierzonego znaczenia.

Filip Obuchowicz, radując się ze zwycięstwa pod Beresteczkiem, zdecydował się na lekki żart, zaprawiony sporą dozą ironii, pod adresem Tatarów i dowodzącego nimi

${ }^{31}$ Ibidem, s. 200-201.

${ }^{32}$ M. Jemiołowski, Pamiętnik..., op. cit., s. 193.

${ }^{33}$ J. W. Poczobut Odlanicki, Pamiętnik, op. cit., s. 128. 
chana. Podkreślając druzgocący charakter zwycięstwa wojsk Rzeczypospolitej oraz rozmiar paniki, w jaką wpadli wrogowie, oznajmia, iż chan ,uciekając aż w Krymie bachmaty rozsiodlal" ${ }^{\prime 4}$.

\section{3. Żarty $\mathrm{z}$ nazw}

Do rzadkości należą natomiast żarty, związane z nazwami miejscowości, rzek czy ludzkimi nazwiskami. Drobysz Tuszyński, opisując walki w województwie czernichowskim, wspomina:

Osobliwie dobywaliśmy miasta Dziewice, pod którym niejeden pożegnał się z tym światem. Taka to była dziewica nietykalna ${ }^{35}$.

Z nazwiska natomiast żartował sobie pewien towarzysz, którego wypowiedź przytacza Jan Chryzostom:

Czego winszując panu Lubomirskiemu, frant jeden, towarzysz Pustoszyński, tak mówi: „Miłościwy dobrodzieju, więcej nam Pan Bóg daje nad to niżeśmy go prosili”. - Spyta Lubomirski: „Jakże to?” — Odpowie ów: „Ato prosiliśmy zawsze: Da pacem, Domine! Da pacem, Domine!; my prosili o jednego, a Pan Bóg nam dał piąci Paców". Bo między więźniami pięć samych Paców było, a wszystko oficerów znacznych ${ }^{36}$.

Mikołaj Jemiołowski, pisząc (z niechęcią) o zawiązaniu w 1663 roku Związku Święconego (myląc go wprawdzie ze Związkiem Pobożnym, który powstał rok wcześniej), komentuje jego - niestosowną zdaniem autora — nazwę:

Już nowe zaciaggi za gotowiznę z podatków na wojsko uchwalonych pod przysięgą, że brat bratu folgować nie będzie, wymyślili i ten zaciąg Pobożnym Związkiem na przekory nazwali ${ }^{37}$.

Pamiętnikarz-historiograf niestosowność widzi bez wątpienia w bratobójczym celu powstałej konfederacji, której to intencji nie sposób oczywiście nazwać „pobożnością" 38 .

${ }^{34}$ Pamiętniki Filipa, Michała i Teodora Obuchowiczów (1630-1707), op. cit., s. 240.

${ }^{35}$ Dwa pamiętniki z XVII wieku, op. cit., s. 53.

${ }^{36}$ J. Pasek, Pamiętniki, op. cit., s. 384. Pamiętnikarz nieco jednak koloryzował, bo Paców do niewoli trafiło tylko trzech; nie zmniejsza to jednak komizmu całej scenki.

${ }^{37}$ M. Jemiołowski, Pamiętnik..., op. cit., s. 324.

${ }^{38}$ Najciekawszym elementem tego opisu jest jednak dostrzeżenie faktu, iż sam Jemiołowski-żołnierz brał czynny i całkiem znaczący udział i w zawiązaniu, i w pracach tego związku, nie żywiąc wówczas najwyraźniej żadnych obiekcji. Ocena zaś Jemiołowskiego-pamiętnikarza jest diametralnie różna. 
Podobną praktykę obserwujemy przy relacjonowaniu porażki wojsk polskich pod Piławcami w 1648 roku, kiedy to - krytykując haniebnie tchórzliwą postawę zwłaszcza pospolitego ruszenia - tak modyfikuje nazwę pola bitwy:

Tak że ta ekspedycyja, nie tak krwawa jak sromotna wielce nazywać by się mogła. Jakoż od niektórych nie pilawiecka, a plugawiecka mianowana była ${ }^{39}$.

U tego samego autora natrafiamy na jeszcze jeden przypadek wykorzystania tego rodzaju ironii. Pisząc o uchwalonym w 1673 roku specjalnym podatku pogłównym (subsidium charitativum), przeznaczonym na wojnę turecką, tak go określa: „Nazwano ten podatek pomoc miłośna, aleć niemiła była" ${ }^{40}$.

Podobny rodzajowo żart, polegający na niezgodnej z rzeczywistym znaczeniem wykładni pewnego pojęcia, przywołał Jemiołowski. Wspomina wpierw o bitych przez Andrzeja Tymfa monetach, zawierających znaczącą domieszkę miedzi (co bardzo obniżało rzeczywistą siłę nabywczą takiej monety), na których znajdował się napis „dat praetium servata salus potiorque metallo est”, co thumaczy: ,jakoby dając znać, że jakoby te orty nie bardzo dobre, atoli jakie [sa] takie żołnierze od Rzeczypospolitej w zasługach brać muszą" ${ }^{* 1}$. Żart dotyczyl tu oczywiście odmiennego niż zamierzone odczytania treści napisu na monetach, jednak nie sposób nazwać go inaczej niż gorzkim, wręcz sarkastycznym, jako że tak niskie machinacje, sprowadzające się do psucia monety, były dokonywane w celu zapłacenia zaległych wobec żolnierzy kwot. Kontrast między żolnierskimi zasługami a metodami ich zaspokojenia jest zbyt mocny, by można mówić wyłącznie o żarcie.

O kwestii tej wspomina również Drobysz Tuszyński, jednak gorzką wymowę osiąga nie poprzez ironię czy zabiegi interpretacyjne, a przez kontrast. Wymienia najpierw działania, do których się uciekano, by uzyskać potrzebne na spłatę zaległego żołdu pieniądze, wyliczając pogłówne, asekurację sreber kościelnych, przebijanie talarów, fałszerstwa Tymfa i Boratyniego, a cały, obszerny akapit kwituje lapidarną pointą: „Przecież dostateczna zapłata wojska nie doszła" ${ }^{2}$.

\section{4. Żartobliwe peryfrazy}

Od czasu do czasu natrafiamy ponadto na żartobliwe peryfrazy, łagodzące niekiedy grozę opisywanych wydarzeń, nie zawsze jednak możemy mieć pewność, czy istotnie

\footnotetext{
${ }^{39}$ Ibidem, s. 53.

${ }^{40}$ Ibidem, s. 411.

${ }^{41}$ Ibidem, s. 319.

${ }^{42}$ Dua pamiętniki zXVII wieku, op. cit., s. 143.
} 
taki charakter był zamierzony — na przykład w przypadku wspomnień Poczobuta często trudno jednoznacznie wskazać, czy dane stwierdzenie, odbierane dziś jako żartobliwe, było takim z punktu widzenia autora; możliwe też jest, że mamy do czynienia $\mathrm{z}$ komizmem niezamierzonym.

I tak wspomniany Poczobut o zranieniu przeciwnika w twarz podczas swego pierwszego w życiu pojedynku mówi, iż dał mu „upominek przez nos” ${ }^{\text {”3 }}$. Słowo „upominek” ma jednoznacznie pozytywną konotację, dlatego też w zestawieniu z zadaną raną pełni zapewne funkcję żartobliwą. Podczas szturmowania wileńskiego zamku w 1660 roku pamiętnikarz o strzałach obrońców powie, iż

dali naszym od zamku mocno pieprzu w nos, którego się i nam po części wąchać dostało. Bardzo lada jaki zapach, który więcej siedmiuset ludzi zaraził śmiertelnie i rzadki wyleczył się z ich naszpikowania, czego się żal Panie Boże $e^{44}$.

Grozę walki oraz rozmiar strat thumi nieco żartobliwa peryfraza, zamieniająca „proch” na „pieprz”. Bardzo podobny zabieg zastosuje również podczas relacjonowania walk nad Dźwiną w 1661 roku, kiedy to o licznie gwiżdżących kulach napisze:

przysłuchaliśmy się pięknemu śpiewaniu cały dzień różnych kul, nut i głosów, które bez ustania szły przez nas. Ale Pan Bóg je roznosit, że nam nic nie szkodziły, ledwie która o blachę szczęknęła, jednak dwóch dragonów zabito i kilku postrzelono ${ }^{45}$.

Znów groza latających wszędzie kul lagodzona jest z jednej strony poprzez określenie wydawanych przez nie dźwięków mianem „śpiewania” (wysłuchali więc całej symfonii), a z drugiej przysłowiem, że „czlowiek strzela, Pan Bóg kule nosi”. Ponieważ wojna z Moskwą urasta miejscami do rangi wojny pobożnej, zatem i szczególna, boska opieka jest zupełnie zrozumiała.

Mniej groźne, choć na pewno bolesne zdarzenie przydarzyło się pewnemu szpiegującemu podczas obrad sejmikowych słudze, którego pochwycono i wyplazowano szablami. Poczobut karę, wymierzoną pechowemu wywiadowcy, określa uroczą peryfrazą:

skoro go pościgniono, tamże zaraz w izbie sejmikowej jęli bracia pasować na rycerstwo, tak dalece, że już drudzy pacierze za jego duszę mówili ${ }^{46}$.

${ }^{43}$ J. W. Poczobut Odlanicki, Pamiętnik, op. cit., s. 124.

${ }^{44}$ Ibidem, s. 138.

${ }^{45}$ Ibidem, s. 152.

${ }^{46}$ Ibidem, s. 254-255. 
Filip Obuchowicz, ciesząc się z kapitulacji wojsk moskiewskich Szeina 25 lutego 1634 pod Smoleńskiem, informuje, że „dział 120 kosztownych zostawił nam Szejn w upominku i inszej strzelby, i rynsztunków bez liczby" ${ }^{\prime 7}$. Kluczowym słowem jest tu oczywiście "upominek”, nadaje ono żartobliwego brzmienia opisywanej scenie. Również u Jemiołowskiego dostrzec możemy podobnego rodzaju peryfrazę, kiedy to czynione podczas trwania Związku Święconego próby przekupstwa poszczególnych ważniejszych konfederatów pamiętnikarz określa omownie jako „złote i srebrne perswazje" ${ }^{48}$.

\section{5. Żarty w kontaktach dyplomatycznych}

$\mathrm{Z}$ pozoru zaskakujące wydaje się natomiast stosunkowo częste występowanie akcentów komicznych w sferze kontaktów dyplomatycznych, jednak podobnego rodzaju praktyki mają za sobą długą, także literacką, tradycję. Nierzadko zdarza się nam bowiem natrafić na informacje o różnego rodzaju mniej lub bardziej dowcipnych wymianach zdań, do których dochodziło podczas rozmów toczonych na rozmaitych szczeblach ${ }^{49}$; jednym z przejawów tego zjawiska - choć niepolegającego na wymianie słów — była znana tradycja wymiany wymownych darów, którym nadawano symboliczne znaczenie, znieważające przeciwnika lub też uwznioślające siebie ${ }^{50}$.

W interesujących nas pamiętnikach natrafiamy na ślady podobnej praktyki, jednak najczęściej ograniczają się one, niestety, do suchych stwierdzeń, że komuś odpowiedziano, posługując się żartem, jakim jednak — tego już się nie dowiadujemy.

I tak Jemiołowski o negocjacjach z Moskalami w roku 1653 pisze:

Przydał na to z nagła, po moskiewsku poseł, mówiąc: że krzywda jego, krzywdą carską być musi, żartami jednak hardość mowej wetowano ${ }^{51}$.

Trudno będzie mówić o swoistym rewanżu, jednak jakościowo podobna scena rozegrać się miała podczas negocjacji między tymi samymi stronami w 1675 roku, kiedy to, jak stwierdza pamiętnikarz, „Zgoła żartownymi i naśmiewającymi się racyjami

\footnotetext{
${ }^{47}$ Pamiętniki Filipa, Michała i Teodora Obuchouriczów (1630-1707), op. cit., s. 212. Ilość dział nota bene przesadzona.

${ }^{48}$ M. Jemiołowski, Pamiętnik..., op. cit., s. 312.

49 Spośród mnogości przykładów przywołajmy dialog między Aleksandrem Macedońskim a piratem Diomedesem, który bez respektu wobec zdobywcy hardo odpowiadał na jego zarzuty.

5n Żeby nie szukać zbyt daleko, przywołajmy choćby znany z tradycji romansu aleksandrowego motyw wymiany darów między Aleksandrem a Dariuszem, kiedy to ten swoisty pojedynek na upominki każda ze stron stara się wygrać, interpretując wymowę otrzymanych przedmiotów na swoją korzyść, „pokonując” tym samym interpretację drugiej strony.

${ }_{51}$ M. Jemiołowski, Pamiętrik..., op. cit., s. 107. Jakie to były żarty, nie wiemy.
} 
tę komisyją Moskwa traktowała"52. Przykładami takich żartobliwych (choć dziś bylibyśmy skłonni nazwać je raczej bałamutnymi lub zbywającymi) odpowiedzi było tłumaczenie, iż posiłki (które nie zostały wysłane) zagarnęli Turcy, zaś Kijowa Moskwa Polakom oddać nie może, bo skoro nie obronili przed Turkami bliższych fortec (szło przede wszystkim o Kamieniec Podolski), to tym bardziej utraciliby Kijów na rzecz tak potężnego nieprzyjaciela.

Każdy czytelnik Sienkiewiczowskiej Trylogii pamięta pyszną scenę, kiedy to w oblężonym przez Szwedów Zamościu Onufry Zagłoba podpowiada Zamoyskiemu dowcipne odpowiedzi, którymi ten zbija z tropu posłującego od Szwedów generała Forgella. Jemiołowski o ofiarowaniu Karolowi Gustawowi Niderlandów wprawdzie nie wspomina, jednak odnotowuje inną odpowiedź Jana Zamoyskiego. Pisze bowiem, iż król szwedzki:

A przy uporze, póty spod Zamościa nie ustąpić deklaruje się, póki go albo szturmem nie dobędzie [...], albo na kilkanaście mil i jednego w dobrach jego nie zostawi. Żartował z tego Zamoyski i powiedział, a za jedno drzewo na zdrajców w lasach moich zostanie ${ }^{53}$.

Owymi zdrajcami, o których wspomina pan na Zamościu, byli zapewne posłujący do niego od Karola Gustawa Polacy — Jan Fryderyk Sapieha oraz Jerzy Niemirycz.

Natomiast zbliżoną do Sienkiewiczowskiego konceptu odpowiedź znajdziemy w dziele Żółkiewskiego. Pan hetman relacjonuje między innymi rozmowy, toczone między nim a Maryną (wówczas już związaną z drugim Dymitrem). Z niesmakiem i dezaprobatą informuje o niewieściej hardości carycy:

Ale on [Dymitr] nie myślił się tym kontentować, a tym więcej jego żona, i jako byla niewiasta ambitiosa, grubo dosyć blekotała: „Niech też król jegomość ustąpi carowi jegomości Krakowa, a car jegomość da królowi jegomości Warszawę̨" ${ }^{54}$.

Jakkolwiek oceniać postać Maryny Mniszchówny, to jej harda odpowiedź stanowiła całkiem logiczną reakcję na bardzo dla cara niekorzystną propozycję króla Zygmunta ${ }^{55}$.

Odpowiedź, uznaną przez Jemiołowskiego za żart, przywołuje pamiętnikarz, opisując działania na Pomorzu Gdańskim w roku 1657. Przytacza żądanie, wystosowane przez szwedzkiego generała Stenbocka pod adresem gdańskiej rady miejskiej, „żeby

\footnotetext{
${ }^{52}$ Ibidem, s. 440.

${ }^{53}$ Ibidem, s. 177.

${ }^{54}$ S. Żółkiewski, Poczatek i progres wojny moskiewskiej, op. cit., s. 85.

${ }^{55}$ Ocena Żółkiewskiego wypływać może z cechującej go niechęci i do impostora, i do jego małżonki, na których temat nie ma nic dobrego do powiedzenia.
} 
albo się sami poddali zawczasu, albo króla Kazimierza wydali" ${ }^{56}$. W odpowiedzi jednak szwedzki feldmarszałek otrzymal taki dictum:

Żartem tej legacyi Gdańsczanie zbyli, i że nie oni teraz rządzą, ale król Polski, Pan ich, tak deklarowali ${ }^{57}$.

W dalszej części opowiadania Jemiołowski doda, iż ufali zarówno w pomoc króla, jak i własne, bardzo liczne, wojsko. Natomiast niezupełnie jasno rysuje się odpowiedź na pytanie, cóż takiego żartobliwego pamiętnikarz dostrzegał w tym responsie.

Obok dyplomatycznych przymówek natrafić możemy również na charakterystyczne dla ówczesnej praktyki wojennej buńczuczne zapowiedzi, kierowane pod adresem przeciwników. Stanisław Żółkiewski wspomina, iż przez bitwą pod Kłuszynem Pontus de la Gardie przechwalał się przed Dymitrem Szujskim, mówiąc:

Gdym był na Wolmierzu z Karolusowymi wzięty, dał mi był hetman szubę rysią, mam ja też teraz dla niego sobolą, co mu oddaruję - tusząc sobie pana hetmana pojmać ${ }^{8}$.

Żółkiewski nie komentuje wprawdzie tego oświadczenia, jednak z kolejnych partii tekstu przebija wyraźne zadowolenie z okazywanego przez stronę moskiewską lekceważenia, które pozwoliło wojskom Rzeczypospolitej na zaskoczenie wroga i w konsekwencji jego pokonanie. Brak komentarza odautorskiego jest zresztą oczywisty, jeśli zważy się na konwencję pisarską, którą posłużył się Żółkiewski. Jak stwierdziła Jadwiga Rytel:

wobec zachowania pelnego incognito autora i zamierzonego oddzielenia autora od postaci występującego w pamiętniku „pana hetmana”, komentarz bezpośredni odgrywa tym mniejszą rolę ${ }^{59}$.

\subsection{Inne żarty}

Wymieniane $\mathrm{w}$ poprzednich punktach żarty poddawały się pewnej systematyce, poza nią pozostaje jednak grupa odautorskich komentarzy, których wspólne zaklasy-

\footnotetext{
${ }^{56}$ M. Jemiołowski, Pamiętnik..., op. cit., s. 231.

${ }^{57}$ Ibidem.

58 S. Żółkiewski, Początek i progres wojny moskieuskiej, op. cit., s. 64. Tym „panem hetmanem" był, oczywiście, sam Żółkiewski, co nadaje całej scenie większego ładunku komicznego. Należy jednak pamiętać, że w tej partii dzieła Żółkiewski relacjonuje jedynie to, co na temat zachowania Pontusa usłyszał, sam bowiem jako narrator nieskłonny jest do wprowadzania w ramy swego utworu elementów humorystycznych.

59 J. Rytel, „Pamiętniki” Paska..., op. cit., s. 95.
} 
fikowanie wydaje się trudne lub wręcz niemożliwe. Przywołajmy tu na prawach przykładu jedynie dwa takie luźne komentarze; jest ich oczywiście więcej.

Drobysz Tuszyński, wspominając Jacka Szemberga, pułkownika dowodzącego lekkimi chorągwiami wołoskimi podczas walk ze Szwedami w roku 1656, stwierdza na jego temat: „a lubo kreatura byla dość niskiego wzrostu, ale serce, że tak rzekę, większe było niż on sam” ${ }^{00}$. Pamiętamy, że wyraz „kreatura” nie miał jeszcze wtedy pejoratywnego znaczenia, jakie nadajemy mu współcześnie, zatem w tym przypadku mamy do czynienia ze stosunkowo rzadkim przypadkiem wykorzystania żartu w funkcji pochwalnej.

$\mathrm{Na}$ osobliwy żart zdobywa się na ogół do nich nieskłonny Druszkiewicz, który, opowiadając o swym pobycie w tatarskiej, a później tureckiej niewoli, wspomina:

Cnotliwy mnie Turczyn kupil, bardzo dobry człowiek (Kałak emir efen-

di) za trzydzieści talarów i za cztery sztuki kindziaku. Zaprawdę bardzom był niedrogi, bom też był nadkaleczony i szaleństwo zmyślałem ${ }^{61}$.

Jeżeli możemy uznać tę wypowiedź za istotnie żartobliwą, to mielibyśmy jeden z rzadkich przykładów autoironii, na którą niełatwo przychodziło zdobywać się naszym pamiętnikarzom.

\section{Wojenne anegdoty}

Z pamiętnikarską narracją najmocniej chyba związane są różnych rozmiarów anegdoty, prezentujące wypadki zaszle podczas opisywanych wydarzeń. Anegdoty te mogą przybierać charakter humorystyczny, nie jest on jednak niezbędny. Nas, z oczywistych względów, interesować będą jedynie te krótkie opowiadania, wplecione w tok narracji, które charakteryzują się choćby minimalnym natężeniem elementu komicznego ${ }^{62}$. Nie będziemy również dociekać, na ile prawdziwe są prezentowane wydarzenia - chyba że rys komiczny im nadany ma odmienną od literackiej motywację. W takich przypadkach przyjdzie posiłkować się ustaleniami badaczy historii XVII stulecia.

Pośród interesujących nas pamiętników zdecydowanie najobfitsze w komicznie zabarwiony materiał anegdotyczny są pamiętniki Paska oraz diariusz Dyakowskiego,

${ }^{60}$ Dwa pamiętniki z XVII wieku, op. cit., s. 45.

${ }^{61}$ S. Z. Druszkiewicz, Pamiętniki 1648-1697, op. cit., s. 88.

62 Nie zawsze będzie to możliwe do jednoznacznego zaklasyfikowania, ponieważ odczucie śmieszności pewnych wydarzeń mogło ulec zmianie w czasie oddzielającym moment spisania pamiętnika od dnia naszej lektury, natykać się również będziemy na anegdoty, które — jak się zdaje — były pisane najzupełniej serio, jednak w odbiorze współczesnego nam czytelnika nabrały rysów niezamierzonej przez autora śmieszności; na ogół będzie się to wiązało z charakterystycznym dla baroku współwystępowaniem sfery sacrum i profanum; z naszego punktu widzenia istotne są oczywiście wyłącznie anegdoty świadomie ujęte w sposób komiczny. 
nieco mniej znajdziemy go w dziełku Poczobuta oraz Niemojewskiego. Nie budzi to oczywiście zdziwienia, jako że dwa przywołane jako pierwsze utwory cechuje podobny mechanizm powstania - stanowią one spisane po wielu latach, a po wielekroć przez cały ten czas opowiadane gawędy ${ }^{63}$. Nie wdając się w zbędne nam przecież ustalenia terminologiczne, zaznaczyć jedynie należy fundamentalny dla „powodzenia” gawędy oraz jej autora fakt: musi być ona na tyle ciekawa i zajmująca, by pozyskać zainteresowanie odbiorców, dlatego też przywołane tu utwory wyraźnie różnią się od pozostałych, zaś ich komiczne nacechowanie wyrasta $\mathrm{z}$ potrzeby zyskania oraz utrzymania uwagi słuchaczy. Jak pisała swego czasu o pamiętniku $\mathrm{Pa}-$ ska Jadwiga Rytel:

niektóre $z$ jego najlepszych opowieści wyodrębniają się poza tym jako rozwinięte, typowe gawędy. Noszą wtedy na sobie wyraźne ślady ustnego, wielokrotnego powtarzania ${ }^{64}$.

Podobny sąd w odniesieniu do diariusza Dyakowskiego formulują jego wydawcy.

Dla egzemplifikacji metod, jakimi posługuje się Dyakowski, przywołajmy dwie tylko anegdoty o akcencie komicznym; w całym dziełku jest ich rzecz jasna więcej.

Po pokonaniu oblegających Wiedeń wojsk tureckich miała miejsce wielka uczta, wydana przez naszych ówczesnych sojuszników $w^{65}$. Nieświadomi jednak znaczenia stroju polskich oficerów i żołnierzy, Niemcy pomylili jednych z drugimi, wskazując towarzyszom honorowe miejsca, zaś oficerów kierując na pośledniejsze. Stało się tak $z$ uwagi na narzucane na zbroje futra — okazalsze (bo tygrysie) nosili towarzysze, więc gospodarze automatycznie uznali, że są one oznaką ważniejszej godności niż noszone przez oficerów proste burki. Dla tak potraktowanych Polaków stało się to okazją do śmiechu. Dyakowski sceny tej w ogóle nie komentuje, pozwalając odbiorcy cieszyć się całym komizmem tej sytuacji.

Innym przejawem komizmu sytuacyjnego była dla pamiętnikarza opowieść, jak to hetman Sieniawski utemperował cesarza Leopolda i nauczył go szacunku dla Polaków. Dyakowski rozpoczyna od stwierdzenia, że cesarz — idąc za podszeptami czułych na cesarski majestat doradców - nie chciał w żaden sposób oddawać honorów i nie zdejmował z głowy kapelusza. Rozsierdzony tym hetman również nie oddał cesarzowi honorów poprzez zdjęcie czapki, zaś kiedy dumny Habsburg wizytował hetmańską chorągiew, doznał kolejnego despektu, jako że chorąży nie pochylił przed nim dzierżonego sztandaru, co zawsze przedtem dla oddania czci gościowi czyniono. Wtedy

\footnotetext{
${ }^{63}$ Sąd ten szczegółowo uzasadnia Władysław Czapliński. Zob. idem, Wstęp w: J. Pasek, Pamiętniki, op. cit., s. 53.

${ }^{64}$ J. Rytel, „Pamiętniki” Paska..., op. cit., s. 77.

${ }^{65}$ Zob. Dyaryusz wideńskiej okazyji..., op. cit., s. 69.
} 
dopiero cesarz dowiedział się, dlaczego tak się stało, ogromnie się przeją i — jak podaje Dyakowski -

Już tedy po uczynieniu sobie tej relacyi, gdy gdzie na którą chorągiew przyjachał, to ledwie się na chorągiew kapeluszem pchał. Nawet wołoskim i tatarskim choragwiom po admonicyi ten honor czynit ${ }^{66}$.

Komicznym akcentem jest tu popadnięcie przez cesarza w przeciwną skrajność wcześniej nie oddawał honorów nikomu, a później nawet tak mało znaczącym w ówczesnej wojskowej hierarchii jednostkom, jakimi były lekkie choragwie ${ }^{67}$. Słuchacze tej gawędy z pewnością doznawali wielkiej przyjemności, wypływającej raz z pognębienia niemieckiej pychy, a z drugiej strony z odwagi jednego $z$ „naszych”.

Poczobut przywołuje wiele anegdot (nie wszystkie z nich możemy uznać za ściśle „wojenne”), pośród nich wskażmy jeden tylko przykład swoistej roztropności pewnego Węgra (jego imienia pamiętnikarz nie wspomina, może go nie znal), który do boju uzbroil się w połówkę podkowy zatkniętą za pas, i traf chciał, że właśnie w tę podkowę trafiła kula, nie czyniąc bohaterowi najmniejszej szkody; sam zainteresowany skomentował to wydarzenia „verum, jaka taka zbrojka dobra" ${ }^{\prime 8}$.

Stanisław Niemojewski z kolei przytoczył zabawną anegdotę o Moskalach, którzy od Polaków, pozostających w niewoli, domagali się okazywania szczególnej czci carowi, co miało się wyrażać w zdejmowaniu okryć głowy podczas odczytywania carskich pism (jeńcy prowadzili z carem obfitą, choć często jednostronną, korespondencję). Polacy, udręczeni dokonanym właśnie obniżeniem i tak niskich racji żywnościowych, odpowiedzieli na to:

Byle co pociesznego usłyszeć do odpuszczenia nas, nie tylko czapkę zdejmiem, ale i niższe odzienie opuściem ${ }^{69}$.

Różnych anegdot można przytaczać więcej, jednak doprowadziłoby to do nadmiernego rozszerzenia niniejszego artykułu; niech te już przywołane wystarczą dla potrzeb egzemplifikacyjnych. Na temat konstrukcji Paskowych anegdot (a sądy te bez trudu możemy zastosować do anegdot opowiadanych przez innych autorów) szczególowe rozważania przeprowadziła, cytowana już, Jadwiga Rytel, zatem do jej pracy pozostaje w tym miejscu odesłać.

\footnotetext{
to Ibidem, s. 71-73.
}

${ }^{67} \mathrm{~W}$ tym miejscu można by się jeszcze zastanawiać, czy i w jakim stopniu na takim ukształtowaniu tej anegdoty zaważył fakt, że sam pamiętnikarz służył później jako porucznik w jednej z takich jednostek.

${ }^{68}$ J. W. Poczobut Odlanicki, Pamiętnik, op. cit., s. 162.

${ }_{69}$ S. Niemojewski, Diariusz drogi spisanej..., op. cit., s. 214. 


\section{Zakończenie}

Bez wątpienia prawdziwym jest sąd, iż siedemnastowieczne pamiętniki wojenne zawierają pewną dozę komizmu, zróżnicowaną w zależności od rozmaitych czynników, których nie sposób dziś już zrekonstruować. Istnieją teksty, w których humorystyczne ukazywanie opisywanych wydarzeń i ich bohaterów pełni znaczącą funkcję (jak np. w pamiętnikach Jana Chryzostoma), dysponujemy sporą ilością dzieł o mniejszym natężeniu elementu komicznego, znamy również i takie pamiętniki, które rysów takich w ogóle są pozbawione.

Z punktu widzenia wykorzystywanych środków komicznego wyrazu na plan pierwszy zdecydowanie wysuwa się żart językowy, często posługujący się ironią w jej klasycznym, retorycznym rozumieniu. Żart ten obejmuje różne sfery prezentowanych zdarzeń, nie zawsze też służy swoiście rozumianej kompromitacji dotkniętych nim osób lub zjawisk, może również pełnić funkcję pochwalną (choć nieczęsto). Miejscem w przestrzeni tekstowej, typowym dla pojawiania się żartu, jest odautorski komentarz.

Kolejnym środkiem wyrazu, w którym objawia się komizm, jest anegdota. Nie każda wprawdzie opowiadana przez pamiętnikarza-narratora anegdota będzie śmieszna (bo taką być przecież nie musiała), jednak natkniemy się na calkiem znaczącą ich liczbę, choć nie u wszystkich autorów. $Z$ anegdotą ściśle związany jest komizm sytuacyjny (choć możliwe są i anegdoty, skonstruowane $z$ wypowiedzi postaci, kiedy to wypowiedzi te same $z$ siebie stanowią źródło komizmu). 